\title{
PENGARUH PAKET EDUKASI SAYANG IBU TERHADAP MOTIVASI IBU DALAM PEMBERIAN ASI EKSKLUSIF DI KABUPATEN PEKALONGAN
}

\author{
Yuni Sandra Pratiwi ${ }^{1}$, Siti Rofiqoh ${ }^{2}$, Herni Rejeki $^{3}$ \\ ${ }^{1,2,3}$ Universitas Muhammadiyah Pekajangan Pekalongan \\ Email: pratiwi_yuni84@yahoo.co.id
}

\begin{abstract}
ABSTRAK
Rendahnya pemberian ASI pada bayi merupakan ancaman yang sangat serius bagi pertumbuhan dan perkembangan bayi sebagai generasi penerus bangsa. Motivasi dan kemampuan yang baik akan meningkatkan peran ibu dalam memberikan ASI pada bayi, sehingga pemberian ASI pada bayi akan mengalami peningkatan. Penelitian ini bertujuan untuk mengidentifikasi pengaruh paket edukasi sayang ibu terhadap motivasi ibu dalam pemberian ASI eksklusif. Metode penelitian quasi eksperiment dengan pendekatan pre and post test nonequivalent control grup. Tempat penelitian di wilayah kerja Puskesmas Buaran dan Wonokerto 2 Kabupaten Pekalongan dengan responden ibu primigravida trimester tiga. Teknik pengambilan sampel menggunakan consecutive sampling yang terdiri dari 38 responden. Uji statistik menggunakan Uji Chi Square. Hasil penelitian menunjukan ada pengaruh paket edukasi sayang ibu terhadap motivasi ibu dalam pemberian ASI pada kelompo intervensi ( $\mathrm{p}<0,05)$. Bagi petugas kesehatan diharapkan lebih menggiatkan program promosi kesehatan, khususnya paket edukasi sayang ibu pada ibu hamil supaya dapat meningkatkan motivasi ibu hamil dalam pemberian ASI pada bayinya.
\end{abstract}

Kata kunci: ASI, Edukasi, Motivasi. 


\title{
INFLUENCE OF MOTHER'S EDUCATION PACKAGE ON MOTHER MOTIVATION IN EXCLUSIVE ASSESSMENT IN PEKALONGAN REGENCY
}

\begin{abstract}
The low milk supply to infants is a very serious threat to the growth and development of infants as the next generation of the nation. Good motivation and ability will increase the role of mothers in giving milk to babies, so that breastfeeding to babies will increase. This study aims to identify the effect of the education package for maternal affection towards maternal motivation in exclusive breastfeeding. A quasiexperimental research method with a non-equivalent control group pre and post test approach. The research site is in the work area of Buaran and Wonokerto 2 Public Health Centers in Pekalongan Regency with three trimester primigravida respondents. The sampling technique used consecutive sampling consisting of 38 respondents. Statistical tests using the Chi Square Test. The results of the study showed that there was an influence of the mother's love education package on mother's motivation in breastfeeding in the intervention group $(p<0.05)$. Health workers are expected to be more active in health promotion programs, especially the education package for mothers to love pregnant women in order to increase the motivation of pregnant women in breastfeeding their babies.
\end{abstract}

Keywords: ASI, Education, Motivation. 


\section{PENDAHULUAN}

Kematian utama bayi di Indonesia disebabkan karena asfiksia, BBLR (berat badan lahir rendah), penyakit lain dan masalah gizi yang diperkirakan lebih banyak terjadi pada usia neonatus (0-28 hari) (Depkes, 2011). Kematian pada bayi yang disebabkan oleh penyakit infeksi berhubungan erat dengan adanya perilaku hidup bersih sehat, sanitasi dasar, pengadaan air bersih, ventilasi, status hunian, status imunisasi, status gizi dan pemberian air susu ibu (ASI). Hal tersebut dapat dijadikan sebagai dasar dalam melakukan tindakan pencegahan terjadinya penyakit infeksi pada bayi, sehingga kematian pada bayi akibat penyakit infeksi dapat dicegah (Depkes, 2007).

Penelitian terkait ASI untuk mencegah kematian bayi telah dilakukan oleh banyak peneliti. Salah satu penelitian yang dilakukan oleh Khairunniyah (2004), mengidentifikasi bahwa pemberian ASI yang rendah pada bayi baru lahir, akan menurunkan kualitas hidup bayi, semakin sedikit bayi yang diberikan ASI eksklusif maka kualitas kesehatan bayi tersebut juga akan semakin memburuk. Hal ini akan berpengaruh terhadap angka kematian bayi, saat bayi mendapatkan ASI maka bayi akan dapat mempertahankan diri dari berbagai macam penyakit infeksi, sehingga resiko kematian bayi dapat dihindarkan, dan diharapkan kualitas hidup bayi akan lebih meningkat. Nurmiati dan Besral (2008), bayi yang mendapatkan ASI mempunyai ketahanan hidup lebih tinggi, dibandingkan dengan bayi yang tidak mendapatkan ASI. Pemberian ASI akan sangat mempengaruhi status ketahanan hidup dan status kesehatan bayi, hal ini didukung oleh data bahwa bayi yang diberikan ASI lebih tinggi dari 6 bulan mempunyai ketahanan hidup sebesar 33,3 kali dibanding bayi yang diberikan ASI kurang dari 4 bulan.

Bayi memerlukan gizi yang dapat diperoleh dari pemberian ASI. Pemberian ASI dimulai 1 jam pertama setelah kelahiran (Siregar, 2007). ASI memiliki kandungan lemak dan kalori yang sangat tinggi sebagai sumber energi, sejumlah mikronutrien, terdapat $70 \%$ vitamin A, $40 \%$ kalsium dan $37 \%$ riboflavin (Dewey, 2001). ASI merupakan zat nutrisi yang sangat penting dan sangat bermanfaat bagi bayi dalam pencegahan terhadap penyakit, membantu proses penyembuhan dari penyakit dan meningkatkan kekebalan tubuh bayi (Depkes RI, 2004).

Rekomendasi yang dikeluarkan oleh WHO (2011), bahwa pemberian ASI pada bayi yang diharuskan adalah pada awal kelahiran yaitu satu jam pertama bayi lahir melalui inisiasi menyusu dini (IMD), memberikan ASI secara eksklusif selama 6 bulan, dan memberikan makanan pendamping ASI sesudah bayi berusia 6 bulan dengan tetap memberikan ASI sampai bayi berusia 2 tahun atau lebih. Kramer dan Kakuman (2002) meneliti tentang durasi yang optimal dalam memberikan ASI, bahwa pemberian ASI selama 6 bulan atau lebih memberikan keuntungan lebih dibanding pemberian ASI selama 4 bulan pada bayi. Keuntungan yang diperoleh salah satunya adalah 
menurunkan angka kesakitan dan kematian yang diakibatkan oleh diare.

Survai Demografi dan Kesehatan Indonesia (SDKI) 2012 melaporkan cakupan ASI eksklusif adalah 42\%, sedangkan laporan dinas kesehatan provinsi tahun 2013 cakupan ASI eksklusif sebesar 54,3\%. Provinsi Jawa Tengah pada tahun 2013 cakupannya sebesar 58,4\% (Kementrian Kesehatan RI, 2014). Laporan Dinas Kesehatan Jawa Tengah memaparkan bahwa cakupan ASI eksklusif pada tahun 2014 meningkat menjadi $60,7 \%$. Kabupaten Pekalongan berada pada peringkat terendah dengan cakupan sebesar 37,3\% (Dinas Kesehatan Jawa Tengah, 2014). Cakupan ASI eksklusif kembali menurun pada tahun 2015 dengan cakupan 30,3\%, dan cakupan terendah di wilayah Puskesmas Wonokerto I sejumlah 22,2\% (Dinas Kesehatan Kabupaten Pekalongan, 2015). Data terbaru yang belum dipublikasikan di bulan Februari tahun 2016 cakupan ASI eksklusif terendah di Puskesmas Buaran dengan prosentase berkisar 14, 22\% (Dinas Kabupaten Pekalongan, 2016).

Prevalensi pemberian ASI pada bayi di Kabupaten Pekalongan menunjukkan adanya penurunan yang signifikan. Penurunan pemberian ASI juga disebabkan oleh masih rendahnya kesadaran masyarakat akan pentingnya ASI bagi bayinya, sehingga masyarakat terutama ibu bayi kurang termotivasi untuk memberikan

ASI (BPPSDMK_Depkes, 2012). Penelitian Saleh, dkk (2009) di Kabupaten Maros Sulawesi Selatan, bahwa ada pengaruh yang efektif dari pendidikan kesehatan yang dilakukan oleh perawat terhadap peningkatan pengetahuan ibu, kemampuan dalam praktek menyusui dan kepercayaan diri ibu dalam memberikan ASI pada bayinya.

Faktor lain yang perpengaruh terhadap pemberian ASI adalah keyakinan dan motivasi terhadap pemberian ASI. Penelitian yang dilakukan oleh Man-Ku dan Chow pada (2010) di Hongkong, bahwa faktor yang cukup berpengaruh dalam pemberian ASI adalah keyakinan dan motivasi ibu. Ibu yang mempunyai motivasi dan keyakinan diri yang baik akan lebih mampu memberikan ASI, dibandingkan ibu yang mempunyai motivasi dan keyakinan rendah. Penelitian lain yang di lakukan oleh Yefrida (1996) di kota Depok, memberikan hasil bahwa keyakinan dan motivasi merupakan variabel yang sangat dominan mempengaruhi kemampuan ibu dalam pemberian ASI. Motivasi yang merupakan dorongan dari dalam atau luar diri seseorang untuk melakukan suatu tindakan, menjadi salah satu dasar penting bagi ibu untuk memberikan ASI. Ketika ibu mempunyai motivasi yang baik dalam memberikan ASI untuk bayinya, maka diharapkan ibu tersebut mempunyai kemampuan yang baik dalam memberikan ASI.

Motivasi dan kemampuan yang baik akan meningkatkan peran ibu dalam memberikan ASI pada bayi, sehingga pemberian ASI pada bayi akan mengalami peningkatan. Rendahnya pemberian ASI pada bayi merupakan ancaman yang sangat serius bagi pertumbuhan dan perkembangan bayi sebagai generasi penerus bangsa. Kondisi inilah yang menyebabkan 
pemerintah membuat peraturan yang mengatur pemberian ASI. Salah satu diantaranya yaitu Peraturan Pemerintah (PP) tentang pemberian ASI yang bertujuan untuk memenuhi hak bayi, dukungan pada ibu dan peran keluarga dalam memberikan ASI (Kementerian Hukum dan HAM, 2012).

Dukungan khusus dari tenaga kesehatan terhadap program Peningkatan Pemberian ASI (PP-ASI) merupakan salah satu faktor yang mempengaruhi keberhasilan pemberian ASI (BPPSDMK_Depkes, 2012). Penelitian yang dilakukan oleh Siregar (2007) di Sumatera, memberikan kesimpulan adanya peranan dan perhatian dari petugas kesehatan pada ibu yang menyusui akan mempengaruhi kemampuan ibu dalam menyusui bayinya. Peranan petugas kesehatan ini bisa dilakukan dengan memberikan pendidikan kesehatan. Pendidikan kesehatan yang dilakukan oleh perawat dengan memberikan informasi pada ibu dan keluarga tentang kiat sukses menyusui (paket edukasi sayang ibu).

Similac (2011) menyatakan bahwa, ibu yang pertama kali menyusui bayinya akan mendapatkan beberapa kesulitan selama proses menyusui bayi. Proses ini dapat dilakukan dengan mudah, jika ibu mendapatkan informasi dari petugas kesehatan, tentang kiat sukses menyusui (paket edukasi sayang ibu). Kemampuan dalam menyusui inilah yang sangat dibutuhkan oleh ibu, agar ibu dapat dengan mudah melakukan kegiatan menyusui yang benar. Berdasarkan paparan di atas, maka peneliti tertarik untuk melakukan penelitian pengaruh paket edukasi sayang ibu terhadap motivasi ibu dalam pemberian ASI eksklusif di Kabupaten Pekalongan.

\section{METODE PENELITIAN}

Penelitian ini menggunakan desain quasi eksperiment dengan pendekatan pre and post test nonequivalent control grup. Populasi dalam penelitian ini adalah ibu primigravida trimester tiga di Wilayah Kerja Puskesmas Buaran dan Wonokerto 2 Kabupaten Pekalongan. Pengambilan sampel menggunakan teknik consecutive sampling. Kriteria inklusi penelitian adalah ibu hamil primigravida trimester tiga, kesadaran ibu kompos mentis, ibu sehat dan tidak mengalami komplikasi dalam kehamilan, ibu yang bersedia menjadi responden, ibu yang dapat berkomunikasi dengan baik, dan dapat membaca serta menulis. Sedangkan kriteria eksklusinya adalah ibu hamil primigravida trimester satu atau dua, ibu hamil dengan mengalami komplikasi. Kemudian 38 responden dibagi menjadi 2, 19 responden kelompok kontrol dan 19 responden kelompok intervensi. Alat ukur yang digunakan adalah kuesioner tentang karakteristik responden dan motivasi ibu dalam pemberian ASI. Kuesioner motivasi ibu dalam pemberian ASI merupakan modifikasi dari teori yang disampaikan oleh Stockdale, et al (2008) yaitu pengukuran skala motivasi menyusui pada primigravida "Breasfeeding Motivational Instuctional Measurement Scale" (BMIMS) yang telah dilakukan uji validitas dan reabilitas dengan hasil valid dan reliabel. 
Kelompok kontrol diberikan leaflet tanpa informasi lanjutan, dan kelompok intervensi diberikan paket edukasi sayang ibu secara terstruktur selama 3 kali selama kehamilan trimester 3. Paket edukasi dilakukan menggunakan media lembar balik. Pengukuran motivasi pada kedua kelompok dilakukan 1 bulan

HASIL DAN PEMBAHASAN

Hasil penelitian tentang karakteristik responden diuraikan pada tabel 1 dan 2 ,

\section{Tabel 1}

Distribusi Frekuensi Responden Berdasarkan Usia Responden di Kabupaten Pekalongan Tahun 2018

\begin{tabular}{cccccc}
\hline Variabel & $\mathbf{n}$ & $\begin{array}{l}\text { Mean- } \\
\text { Median }\end{array}$ & SD & (Min-Max) & 95\% CI \\
\hline Usia & 38 & 26 & 4,460 & $20-38$ & $24,53-27,47$ \\
& & 25 & & & \\
\hline
\end{tabular}

Tabel 1 menunjukan rata-rata usia responden adalah 26 tahun, dengan standar deviasi 4,660 tahun. Usia minimal 20 tahun dan usia maksimal 38 setelah persalinan. Berdasarkan uji normalitas data menggunakan Colmogorof Smirnov, diketahui data berdistribusi normal, maka uji bivariat yang digunakan adalah uji Uji Chi Square dengan confident interval $95 \%$ dan alfa 0,05 .

sedangkan skor motivasi diuraikan pada tabel 3 dan 4.

\section{Tabel 2}

Distribusi Frekuensi Responden Berdasarkan Pendidikan, Pekerjaan, Pandangan Budaya dan Kepercayaan, serta Dukungan Suami Responden di Kabupaten Pekalongan Tahun 2018

\begin{tabular}{clcc}
\hline No & \multicolumn{1}{c}{ Variabel } & Frekuensi & Presentase \\
\hline 1. & Pendidikan & & \\
& a. Dasar & 22 & 57,9 \\
& b. Tinggi & 16 & 42,1 \\
\hline 2. & Pekerjaan & & \\
& a. Tidak Bekerja & 21 & 55,3 \\
$\quad$ b. Bekerja & 17 & 44,7 \\
\hline 3. & Pandangan Budaya dan Kepercayaan & & \\
& a. Kurang & 28 & 73,7 \\
& b. Baik & 10 & 26,3 \\
\hline 4. Dukungan Suami & & \\
& a. Kurang & 17 & 44,7 \\
b. Baik & 21 & 55,3 \\
\hline
\end{tabular}

Tabel 2 menunjukan bahwa karakteristik responden adalah hampir sebagian berpendidikan dasar, yaitu 22 94 tahun. Hasil estimasi interval dapat disimpulkan bahwa 95\% diyakini ratarata ibu menyusui adalah diantara 24,53 tahun sampai dengan 27,47 tahun. 
pandangan budaya dan kepercayaan yang kurang baik dalam menyusui, yaitu 28 responden $(73,7 \%)$, hampir sebagian mempunyai dukungan suami yang baik dalam menyusui, yaitu 21 responden $(55,3 \%)$.

Tabel 3

Distribusi Frekuensi Perbedaan Nilai Rata-Rata (Rerata) Skor Pre Test dan Post Test Motivasi Responden dalam Pemberian ASI Antar Kelompok Intervensi dan Kelompok Kontrol di Kabupaten Pekalongan Tahun 2018

\begin{tabular}{llccccccccc}
\hline No & Variabel & Kelp & $\begin{array}{c}\text { Pre/Post } \\
\text { Test }\end{array}$ & Mean & SD & SE & t & $\begin{array}{c}\text { P } \\
\text { value }\end{array}$ & $\begin{array}{c}\text { Mean } \\
\text { diff }\end{array}$ & 95\% CI \\
\hline \multirow{2}{*}{1} & Motivasi & $\mathrm{K}$ & Pre Test & 39,47 & 5,28 & 1,21 & 2,74 & 0,97 & 4,21 & $1,0-7,3$ \\
& ibu dalam & & Post Test & 38,84 & 5,36 & 1,23 & & & & \\
\cline { 2 - 11 } & pemberian & I & Pre Test & 35,26 & 4,10 & 0,94 & 0,03 & 0,00 & 0,05 & $-2,7-2,8$ \\
& ASI & & Post Test & 38,79 & 2,74 & 0,62 & & & & \\
\hline
\end{tabular}

Tabel 3 menunjukan bahwa pada kelompok kontrol diketahui, rerata skor motivasi ibu dalam pemberian ASI sebelum perlakuan adalah 39,47 dengan SD 5,28, setelah dilakukan intervensi rerata skor motivasi ibu dalam pemberian ASI setelah perlakuan adalah menurun, yaitu 38,84, dengan SD 5,36. Hasil analisis lebih lanjut menyimpulkan bahwa tidak ada perununan yang bermakana antara skor motivasi ibu dalam pemberian ASI sebelum dan sesudah pada kelompok kontrol $(p=0,97 ; \alpha=0,05)$.
Pada kelompok intervensi diketahui, rerata skor motivasi ibu dalam pemberian ASI sebelum perlakuan adalah 35,26 dengan SD 4,10, setelah dilakukan intervensi rerata skor motivasi ibu dalam pemberian ASI setelah perlakuan adalah meningkat, yaitu 38,79, dengan SD 2,74. Hasil analisis lebih lanjut menyimpulkan bahwa ada peningkatan yang bermakana antara skor motivasi ibu dalam pemberian ASI sebelum dan sesudah pada kelompok intervensi $(\mathrm{p}=0,00$; $\alpha=0,05$ ).

\section{Tabel 4}

Distribusi Frekuensi Selisih Skoring Motivasi Ibu Dalam Pemberian ASI Pada Kelompok Kontrol Dan Kelompok Intervensi Di Kabupaten Pekalongan Tahun

\begin{tabular}{|c|c|c|c|c|c|c|c|c|}
\hline & & \multicolumn{7}{|c|}{2018} \\
\hline No & Variabel & Kelp & Mean & $\mathrm{SD}$ & $\mathrm{T}$ & $\begin{array}{c}\mathrm{p} \\
\text { value }\end{array}$ & $\begin{array}{c}\text { Mean } \\
\text { diff }\end{array}$ & $95 \% \mathrm{CI}$ \\
\hline 1 & $\begin{array}{l}\text { Motivasi ibu dalam } \\
\text { pemberian ASI }\end{array}$ & & & & & & & \\
\hline & Selisih & $\begin{array}{c}\mathrm{K} \\
\mathrm{I}\end{array}$ & $\begin{array}{r}-0,63 \\
3,53\end{array}$ & $\begin{array}{l}7.07 \\
5.63\end{array}$ & 2,71 & 0,00 & 4,21 & $1,09-7,32$ \\
\hline & Post Test & $\begin{array}{l}\mathrm{K} \\
\mathrm{I}\end{array}$ & $\begin{array}{l}38,84 \\
38,79\end{array}$ & $\begin{array}{l}5,36 \\
2,74\end{array}$ & 0,038 & 0,00 & 0,53 & $-2,78-2.85$ \\
\hline
\end{tabular}

Tabel 4 menunjukan bahwa pada kelompok kontrol selisih skor motivasi ibu dalam pemberian ASI sebelum dan sesudah perlakuan terjadi penurunan, yaitu -0,63 dengan SD 7.07, berbeda dengan kelompok intervensi terjadi peningkatan selisih skor motivasi ibu 
dalam pemberian ASI sesudah perlakuan, yaitu 3,53 dengan SD 5,63.

Pada kelompok kontrol skor motivasi ibu dalam pemberian ASI sesudah perlakuan terjadi peningkatan, yaitu 38,84 dengan SD 5,36 sama dengan peningkatan skor motivasi ibu dalam pemberian ASI sesudah perlakuan yaitu 38,79 dengan SD 2,74.

Berdasarkan tabel 1 menunjuka bahwa rata-rata usia responden adalah 26 tahun, usia minimal 20 tahun dan usia maksimal 38 tahun. Usia dihitung dari hari pertama lahir sampai dengan saat berulang tahun, biasanya usia dinyatakan dalam tahun. Usia dapat dijadikan salah satu patokan pada seorang individu untuk melihat tingkat kematangan secara biologis maupun psikologis (Nursalam, 2008). Usia 20 38 tahun pada responden penelitian ini termasuk kedalam rentang usia dewasa. Dimana pada retang usia tersebut dianggap sebagai masa reproduksi yang baik dalam pemberian ASI. Seorang ibu dalam rentang usia dewasa sudah mempunyai kematangan secara fisik.

Pendidikan pada responden adalah hampir sebagian berpendidikan dasar. Soeparmanto dan Pranata (2005), ibu menyusui dengan karakteristik berpendidikan dasar mempunyai proporsi lebih besar dibandingkan dengan yang berpendidikan tinggi, tetapi tingkat kemaknaan dalam pemberian ASI adalah sama antara ibu yang berpendidikan dasar dengan berpendidikan tinggi. Berbeda dengan hasil penelitian Kemalasari (2018), yang mengidentifikasi bahwa pendidikan tinggi merupakan faktor yang mempengaruhi pemberian ASI.
Informasi untuk meningkatkan kualitas hidup dapat diperoleh dengan pendidikan tinggi, semakin tinggi pendidikan maka semakin mudah orang mendapat informasi. Hasil penelitian didapatkan bahwa pekerjaan pada ibu menyusui adalah sebagian besar ibu tidak bekerja. Kemalasari (2008); Rohani (2009) ibu menyusui yang paling banyak adalah tidak bekerja. Ibu yang tidak bekerja dianggap mempunyai waktu luang yang banyak dalam memberikan ASI pada bayi, sedangkan ibu yang bekerja dianggap sibuk dan tidak mempunyai waktu untuk menyusui bayinya.

Pandangan budaya dan kepercayaan dalam menyusui pada ibu adalah hampir sebagian mempunyai pandangan budaya dan kepercayaan yang kurang baik dalam menyusui. Sidi, dkk (2010) bahwa adat dan istiadat tempat tinggal ibu berpengaruh terhadap pemberian ASI. Ludin (2008) juga menyatakan bahwa budaya dan kepercayaan yang dianut seseorang ibu dalam memberikan ASI akan berpengaruh terhadap keputusannya dalam memberikan ASI. Ibu yang mempunyai pandangan budaya dan kepercayaan yang baik dalam menyusui akan lebih termotivasi dalam memberikan ASI.

Dukungan suami pada responden adalah hampir sebagian mempunyai dukungan suami baik dalam menyusui. Penelitian ini sejalan dengan penelitian Al-Akour, et al (2010), bahwa faktor yang sangat berpengaruh terhadap keinginan ibu untuk menyusui adalah dukungan suami serta keluarga dalam pemberian ASI. Dukungan suami merupakan suatu upaya yang dilakukan oleh seorang 
suami baik secara moral maupun tindakan nyata yang diberikan pada istrinya untuk memberikan motivasi dalam memberikan ASI pada bayinya. Dukungan suami sangat diperlukan oleh ibu dalam hal pengambilan keputusan untuk memberikan ASI, ibu akan lebih termotivasi dan merasa percaya diri ketika menyusui (Malau, 2010).

Berdasarkan tabel 3 pada kelompok kontrol diketahui, bahwa tidak ada penurunan yang bermakna antara skor motivasi ibu dalam pemberian ASI sebelum dan sesudah perlakuan. Pada kelompok intervensi terdapat peningkatan yang bermakna antara skor motivasi ibu dalam pemberian ASI sebelum dan sesudah perlakuan. Berdasarkan tabel 4 pada kelompok kontrol selisih sekor motivasi ibu dalam pemberian ASI sebelum dan sesudah perlakuan terjadi penurunan, berbeda dengan kelompok intervensi terjadi peningkatan selisih skor motivasi ibu dalam pemberian ASI sesudah perlakuan terjadi peningkatan.

Prosedur pengambilan data pada kelompok kontrol dan kelompok intervensi dilakukan sebelum perlakuan dan sesudah perlakuan. Pengambilan data yang dilakukan pada kelompok kontrol yaitu dengan memberikan pre test kuesioner motivasi ibu dalam pemberian ASI, memberikan leaflet tanpa diberikan informasi lanjutan, kemudian memberikan post test kuesioner motivasi ibu dalam pemberian ASI. Sedangkan pengambilan data yang dilakukan pada kelompok intervensi yaitu memberikan pre test kuesioner motivasi ibu dalam pemberian ASI, melakukan pendidikan kesehatan terstruktur sebanyak 3 kali pertemuan dengan menggunakan media yang menarik, kemudian memberikan post test kuesioner motivasi ibu dalam pemberian ASI.

Pada kelompok kontrol mendapat leaflet tanpa ada pemberian informasi yang lebih dari petugas kesehatan seperti pada kelompok intervensi, yaitu pemberian pendidikan kesehatan terstruktur sebanyak 3 kali pertemuan dengan menggunakan media yang menarik, sehingga pada kelompok kontrol skor motivasi ibu dalam pemberian ASI sesudah perlakuan lebih kecil dibandingkan dengan kelompok intervensi. Ibu memerlukan pengetahuan dan pemberian informasi untuk mengatasi masalah pada saat pemberian ASI yang dapat diperoleh dari petugas kesehatan. Informasi mengenai manfaat menyusui bagi bayi, ibu dan keluarga, makanan ibu menyusui, cara menyusui yang benar, cara mengatasi masalah saat menyusui, cara menyusui pada ibu bekerja dari petugas kesehatan sangat besar pengaruhnya ketika ibu memberikan ASI pada bayinya. Ibu-ibu biasanya akan mempunyai motivasi dan keyakinan diri yang baik untuk dapat menyusui bayinya karena sudah mendapatkan pengetahuan dan informasi sebelumnya (Sidi, dkk, 2010; Departemen of Health and Human Services, 2011).

Heriandja (2007) menyatakan bahwa motivasi seseorang didukung oleh adanya motif atau pendorong, yang terjadi karena adanya keinginan yang mendorong untuk memenuhi suatu kebutuhan dari dalam diri seseorang, hai 
ini disebabkan oleh karena adanya tuntutan fisik dan psikologis yang muncul melalui mekanisme sistem biologis manusia. Ketika ibu menyusui mendapatkan dukungan yang lebih banyak dari orang disekelilingnya terutama dari petugas kesehatan, maka ibu tersebut diharapkan mempunyai motivasi lebih besar juga untuk merawat dan memberikan ASI bagi bayinya.

Ibu memberikan ASI pada bayinya dipengaruhi oleh faktor motivasi. Berdasarkan penelitian Racine, et al., (2011) bahwa pengetahuan tentang menyusui dapat mempengaruhi motivasi ibu dalam memberikan ASI. Faktor intrinsik yang dapat mempengaruhi motivasi adalah pemberian informasi dan pengetahuan untuk menyusui, sedangkan faktor ekstrinsik adalah dukungan keluarga dan petugas kesehatan. Stockdale (2007) menyatakan bahwa kurang pengetahuan dan dukungan dari petugas kesehatan berpengaruh terhadap motivasi ibu dalam pemberian ASI pada bayi.

Faktor ekstrinsik lain yang dapat mempengaruhi motivasi seseorang untuk melakukan suatu perubahan dalam lingkungan, adalah penghargaan berupa pujian dan reward sangat dibutuhkan oleh seseorang yang telah melakukan motivasi untuk berubah. Penghargaan ini bertujuan untuk memenuhi keinginan agar dapat mengaktualisasikan diri di lingkungannya (Hariandja, 2007). Hal ini sejalan dengan hasil pada penelitian ini, bahwa ibu pada kelompok kontrol mempunyai skor motivasi yang rendah sesudah diberikan perlakuan, berbeda dengan ibu pada kelompok intervensi mempunyai skor motivasi lebih tinggi sesudah perlakuan. Pada kelompok intervensi diberikan perlakuan terstruktur selama 3 kali pertemuan, pada pertemuan ke 3 peneliti melakukan evaluasi dan pujian terhadap ibu, sehingga ibu lebih termotivasi untuk memberikan ASI pada bayinya.

\section{SIMPULAN}

Kesimpulan dari penelitian ini adalah :

1. Karakteristik dari 38 responden usia, pendidikan, pekerjaan, pandangan budaya dan kepercayaan dalam menyusui, serta dukungan suami didpatkan hasil bahwa rata-rata usia ibu menyusui adalah 26 tahun, hampir sebagian berpendidikan dasar, sebagian besar tidak bekerja, hampir sebagian mempunyai pandangan budaya dan kepercayaan yang kurang baik dalam menyusui, serta hampir sebagian mempunyai dukungan suami yang baik dalam menyusui.

2. Pada kelompok intervensi terdapat peningkatan bermakana antara skor motivasi ibu dalam pemberian ASI sebelum dan sesudah perlakuan. 
3. Pada kelompok kontrol tidak ada penurunan yang bermakna antara skor motivasi ibu dalam pemberian ASI sebelum dan sesudah perlakuan.

4. Pada kelompok intervensi terjadi peningkatan selisih skor motivasi ibu dalam pemberian ASI sesudah perlakuan.

\section{UCAPAN TERIMA KASIH}

Pada kesempatan ini, peneliti ingin mengucapkan terima kasih kepada berbagai pihak yang telah membantu terwujudnya penelitian ini :
1. Rektor Universitas
Muhammadiyah Pekajangan Pekalongan.

2. Dekan Fakultas Ilmu Kesehatan Universitas Muhammadiyah Pekajangan Pekalongan.

3. Ketua Program Studi Diploma Tiga keperawatan Fakultas Ilmu Kesehatan Universitas Muhammadiyah Pekajangan Pekalongan.

4. Ketua Lembaga Penelitian dan Pengabdian Masyarakat Fakultas Ilmu kesehatan Universitas Muhammadiyah Pekajangan Pekalongan.

5. Bapeda Kabupaten Pekalongan.

6. Dinas Kesehatan Kabupaten pekalongan.

7. Kepala Puskesmas Buaran Kabupaten Pekalongan.

8. Kepala Puskesmas Wonokerto 2 Kabupaten Pekalongan.

\section{DAFTAR PUSTAKA}

Al-Akour, N.A., Khassawneh, M.Y., Khader, Y.S., Ababneh, A.A., \& Haddad, A.M. (2010). Factors affecting intention to breastfeed among Syrian and Jordanian mothers: A comparative crosssectional study. International Breastfeeding Journal, 5(6), 2-8.

BPPSDMK_Depkes. (2012). Banyak sekali manfaat ASI bagi bayi dan ibu. 3 Februari 2017. http://www.bppsdmk.depkes.go. $\mathrm{id} /$ index.php?option=comconten $\mathrm{t} \&$ view $=$ article \&id=170: banyaksekali-manfaat-asi-bagi-bayidan-ibu

Departemen of Health and Human Services. (2011). Your guide to breastfeeding. Washington: Office on Women's Health.

Depkes. (2007). Buku saku: Pelayanan kesehatan anak di rumah sakit. Jakarta: Departemen Kesehatan RI.

Depkes. (2011). Materi advokasi-BBL kematian bayi. 2 Februari 2017. http://www.gizikia.depkes.go.id/ wpcontent/uploads/downloads/2 011/01/Materi-AdvokasiBBL.pdf

Depkes RI. (2004). Asi eksklusif untuk ibu bekerja. Jakarta: Dirjen Binkesmas Direktorat Gizi Masyarakat.

Dewey, K. (2001). Guiding principles for complementary feeding of the breastfeed child. Washington: Pan American Health Organization World Health Organization. 
Dinas Kesehatan Provinsi Jawa Tengah, 2014, Profil Kesehatan Provinsi Jawa Tengah Tahun 2014, Semarang, Dinas Kesehatan Provinsi Jawa Tengah

$$
\begin{aligned}
& \text { Dinas Kesehatan Kabupaten } \\
& \text { Pekalongan, 2015, Profil } \\
& \text { Kesehatan Kabupaten } \\
& \text { Pekalongan 2015, Pekalongan, } \\
& \text { Dinas Kesehatan Kabupaten }
\end{aligned}
$$

Hariandja, M. (2007). Manajemen sumber daya manusia. Jakarta: Grasindo.

Hasibuan, M. (2007). Manajemen sumber daya manusia. Jakarta: Bumi Aksara.

Kementerian Hukum \& HAM. (2012). PP-ASI eksklusif. Jakarta: Bahan Harmonisasi Kementerian Hukum dan HAM.

Kementrian Kesehatan Republik Indonesia, 2014, Situasi dan Analisis ASI Eksklusif. Jakarta, Pusat Data dan Informasi kementrian Kesehatan Republik Indonesia.

Kemalasari, S. (2008). Pengaruh karakteristik istri dan partisipasi suami terhadap pemberian ASI eksklusif di kecamatan Setalasari Pematang siantar, Tesis.Sumatra: USU Repository.

Khairunniyah. (2004). Pemberian air susu ibu eksklusif ditinjau dari faktor motivasi, persepsi, emosi, dan sikap pada ibu yang melahirkan, Tesis. Bandung: Universitas Padjadjaran.
Kramer, M., \& Kakuma, R. (2002). The optimal duration of exclusive breasfeeding: A systematic review. Switzerland: WHO.

Ludin, H.B., Subhilhar., \& Lubis. Z. (2008). Pengaruh sosial budaya masyarakat terhadap tindakan pemberian ASI eksklusif, Tesis. Sumatra Utara: USU Repository.

Malau, A.E.T., Erniyati., \& Darti. N.E. (2010). Hubungan dukungan suami dan kemauan ibu memberikan ASI eksklusif. Sumatra: USU Repository.

Man-Ku, C., \& Chow, S.K.Y. (2010). Factors influencing the practice of exclusive breastfeeding among Hongkong Chinese women: A questionnaire survey. Journal of Clinical Nursing, 19, 2434-2445.

Nurmiati., \& Besral. (2008). Pengaruh durasi pemberian ASI terhadap ketahanan hidup bayi di Indonesia. Makara Kesehatan, 12(2), 47-52.

Nursalam. (2008). Konsep dan penerapan metode penelitian ilmu keperawatan, pedoman skripsi, tesis, dan instrument penelitian keperawatan. Jakarta: Salemba Medika.

Racine, E.F., Frick, K.D., Strobino, D., Laura M. Carpenter, L.M., Milligan, R., \& Pugh, L.C. (2011). How motivation influences breastfeeding duration among low-income women. J Hum Lact, 25(2), 17318. 
Rohani., Yustina, L., Fauzi (2009). Pengaruh karakteristik ibu menyusui terhadap pemberian ASI eksklusif di wilayah kerja Puskesmas Teluk Kecamatan Secanggang Kabupaten Langkat, Tesis. Sumatra: USU eRepository.

Saleh, A., Nurachmah, E., As'ad, S., \& Hadju, V. (2009). Pengaruh pendidikan kesehatan dengan pendekatan modelling terhadap pengetahuan, kemampuan praktek dan percaya diri ibu dalam menstimulasi tumbuh kembang bayi 0-6 bulan di Kabupaten Maros. 3 Febuari 2017. pasca.unhas.ac.id/jurnal/4d fd694e7da095c426fa76ffbdf2b3 ea.pdf

Sidi, I.P.S., Suradi, R.S., Masoara, S., Boedihardjo, S.D., \& Martono, W. (2010). Manajemen laktasi (4th ed.). Jakarta: PERINASIA.

Similac. (2011). Helpful tips for breastfeeding your baby. California: Abbot Nutrition.

Siregar, A. (2007). Faktor-faktor yang mempengaruhi pemberian ASI oleh ibu yang melahirkan. Sumatera: USU Digital library.

Soeparmanto, P., Pranata, S. (2005). Faktor yang mempengaruhi pemberian ASI eksklusif pada bayi. Buletin Penelitian Sistem Kesehatan, 8(1), 1-7.

Stockdale, J. (2007). Successful breastfeeding promotion: A motivational model of informational design applied and tested. Northern Ireland: (NHS) Research \& Development Office.

WHO. (2011). Exclusive breastfeeding for six months best for babies everywhere. 2 Februari 2017. http://www.who.int/nutrition/top ics/exclusive breastfeeding forsixmonths best for babies everywhere /en/

Yefrida. (1996). Faktor-faktor yang berhubungan dengan perilaku ibu dalam pemberian ASI eksklusif, di wilayah kerja puskesmas Pancoran Mas kelurahan Depok kecamatan Pancoran Mas kotif Depok tahun 1996. 2 Febuari 2017. http://lontar.ui.ac.id/opac/themes /libri2/detail.jsp?id=79056\&loka si $=$ lokal 